\title{
The Brussels International Business Court: Initial Overview and Analysis
}

\author{
Erik Peetermans \& Philippe Lambrecht*
}

\begin{abstract}
In establishing the Brussels International Business Court (BIBC), Belgium is following an international trend to attract international business disputes to English-speaking state courts. The BIBC will be an autonomous business court with the competence to settle, in English, disputes between companies throughout Belgium. This article focuses on the BIBC's constitutionality, composition, competence, proceedings and funding, providing a brief analysis and critical assessment of each of these points. At the time of writing, the Belgian Federal Parliament has not yet definitively passed the Bill establishing the BIBC, meaning that amendments are still possible.
\end{abstract}

Keywords: international jurisdiction, English, court language, Belgium, business court

\section{Introduction}

The planned establishment of the Brussels International Business Court (BIBC), an English-speaking business court, represents a first for Belgium, although similar courts already exist or are in the process of being set up in other jurisdictions.

This article briefly presents a few key aspects of the BIBC. Following a brief discussion of the reasons why the Belgian legislature decided to establish an Englishspeaking business court (Section 2), the article considers the constitutional issues arising from the creation of the BIBC (Section 3). There then follows a more detailed examination of the court's composition (Section 4), competence (Section 5), procedural rules (Section 6) and, last but not least, funding (Section 7).

At the time of writing, the Belgian Federal Parliament had not yet had a final vote on the Bill establishing the Brussels International Business Court, meaning that

\footnotetext{
Philippe Lambrecht is the Director-Secretary General at the Federation of Enterprises in Belgium (FEB). Erik Peetermans is a legal adviser at the Federation of Enterprises in Belgium (FEB). The opinions expressed by the authors in this article are their own. A previous, less extensive analysis of the BIBC can be found in (i) P. Lambrecht and E. Peetermans, 'Brussels International Business Court - vers un tribunal commercial international anglophone à Bruxelles', 2018/1 Juriste International 80 (2018), and also (ii) P. Lambrecht, E. Peetermans, E. Plasschaert \& M. Van Steenbergh, 'Korte schets van het Brussels International Business Court' (article on file at the Belgian Institute of Company Lawyers: Instituut voor Bedrijfsjuristen/Institut des juristes d'entreprise (ed.), Tendensen in het Bedrijfsrecht - Het Burgerlijk Recht in Beweging (Brussels: Larcier) (2018)).
}

amendments are still possible. This article is based primarily on the text of the Bill submitted by the Federal Government to the Belgian House of Representatives on 15 May 2018 as well as subsequent debates in the House Justice Committee. ${ }^{1}$

The aim is for the BIBC to be operational by 1 January 2020 at the latest. ${ }^{2}$

\section{Motivation}

Business activities can give rise to disputes. As more business is carried out transnationally, disputes too are becoming more international. Private international law provides a framework for resolving such international business disputes. ${ }^{3}$ It allows parties to freely choose
1. Bill establishing the Brussels International Business Court, Parl. St./Doc. parl. (Parliamentary Documents): Kamer/Chambre (Belgian House of Representatives) 54, 3072/001; 'Verslag van de eerste lezing namens de commissie voor de Justitie'/'Rapport de la première lecture fait au nom de la commission de la Justice' (Report on the first reading on behalf of the Justice Committee), Parl. St./Doc. parl. (Parliamentary Documents): Kamer/Chambre (Belgian House of Representatives) 54, 3072/007; 'Verslag van de tweede lezing namens de commissie voor de Justitie'/'Rapport de la deuxième lecture fait au nom de la commission de la Justice' (Report on the second reading on behalf of the Justice Committee), Parl. St./Doc. parl. (Parliamentary Documents): Kamer/ Chambre (Belgian House of Representatives) 54, 3072/010. For the ease of the reader, the article mostly refers to the proposed modifications to the Belgian Judicial Code instead of the articles of the Bill establishing the Brussels International Business Court.

2. Art. 63 of the Bill establishing the Brussels International Business Court, Parl. St./Doc. parl. (Parliamentary Documents): Kamer/Chambre (Belgian House of Representatives) 54, 3072/001.

3. J. Hoeben, A.L.M. Keirse \& M.D. Reijneveld, 'Opteren voor de Netherlands Commercial Court', 2017/2 Contracteren - Tijdschrift voor de Contractspraktijk 37 (2017). Belgian private international law (PIL) is enshrined in the Code of Private International Law, whose Art. 2 reaffirms the precedence of European and international PIL rules. Act of 16 July 2004 holding the Code of Private International Law, published in the Belgisch Staatsblad/Moniteur belge (Belgian Official Gazette) of 27 July 2004 
their preferred jurisdiction ${ }^{4}$ and the legal rules they deem applicable should a dispute arise..$^{5,6}$

Companies can choose from a number of dispute resolution mechanisms. There are a wide range of legal and paralegal solutions on offer - especially to companies operating internationally. ${ }^{7}$ As well as conventional legal proceedings, conciliation, mediation and arbitration, other options include specialist state courts and commercial courts such as the BIBC. A company will seek the most suitable means of settling a dispute. For example, it may be that arbitration is not always the right choice for small and medium-sized enterprises with international operations. ${ }^{8}$

One key factor here is the use of English in state courts. There are various initiatives in this area, differing significantly in manner and extent ${ }^{9}$ but all aiming to provide greater scope for the use of English in state courts, in addition to the official language(s) of the country concerned. ${ }^{10}$

In short, the following reasons are cited for establishing the BIBC:

- Firstly, Belgium is not the only country to establish an English-speaking business court handling international trade disputes. Such courts already exist in

4. For European Union (EU) Member States, in terms of applicable law, see (i) Council Regulation 593/2008, OJ 2008 L 177/6 ('Rome I'), and (ii) Council Regulation 864/2007, OJ 2007 L 199/40 ('Rome II'). For non-EU Member States (third countries), see the Hague Convention of 15 June 1955 on the Law Applicable to International Sales of Goods.

5. For EU Member States, in terms of choice of jurisdiction, see (i) Council Regulation 1215/2012, OJ 2012 L 351/1 ('Brussels la'), which entered into force on 10 January 2015, (ii) the Hague Convention of 30 June 2005 on Choice of Court Agreements, ratified by the European Union and also Mexico and Singapore, and (iii) the Lugano Convention on Jurisdiction and the Recognition and Enforcement of Judgments in Civil and Commercial Matters for Denmark, Iceland, Norway and Switzerland.

6. E. Dirix, 'Procederen in het Engels', 81/2 Rechtskundig Weekblad 42 (2017).

7. This freedom of choice results in a global market in terms of applicable jurisdiction and law in certain legal domains. For an analysis of this international regulatory competition, see $\mathrm{H}$. Eidenmuller, 'The Transnational Law Market, Regulatory Competition, and Transnational Corporations', 18(2) Indiana Journal of Global Legal Studies 707 (2011); M. Neekilappillai, 'Netherlands Commercial Court: regelgevingsconcurrentie op de markt voor geschilbeslechting', 23 Nederlands Juristenblad 1594 (2017)

8. Queen Mary University of London (2018), 2018 International Arbitration Survey - The Evolution of International Arbitration, at 8.

9. A comparative analysis of these projects is beyond the scope of this article. For this we refer to Haut Comité Juridique de la Place Financière de Paris (Legal High Committee for Financial Markets of Paris), 'Les chambres spécialisées "business friendly" (Allemagne, Dubaï, Espagne, PaysBas, Qatar, Singapour) - Étude réalisée par le bureau de droit comparé du SAEI', Annex 3 to Haut Comité Juridique de la Place Financière de Paris, Préconisation sur la mise en place à Paris de Chambres spécialisées pour le traitement du contentieux international des affaires (2017), available at: http://hcjp.fr/avis-et-rapports-copier (an English version of this report (Legal High Committee for Financial Markets of Paris, Recommendations for the creation of special tribunals for international business disputes (2017)) is available at: http://hcjp.fr/ opinions-and-reports-copier (last visited on 1 December 2018) but does not include this annex).

10. C.A. Kern, 'English as a court language in continental courts', 5(3) Erasmus Law Review 187 (2012).
London, ${ }^{11}$ Singapore ${ }^{12}$ and Dubai. ${ }^{13}$ Closer to home, the process of establishing the Netherlands Commercial Court has recently come to an end. ${ }^{14}$ In France, the International Chamber of the Paris Court of Appeal has been hearing cases in English since 1 March 2018. ${ }^{15}$ By setting up the BIBC, Belgium aims to compete with these courts in other countries.

- Secondly, an effective BIBC will enhance Brussels' international standing, complementing the Belgian capital's status as the de facto capital of the European Union and home to many international companies, institutions and universities. International players will no longer have to go abroad to settle disputes in English. In addition, the BIBC will tap into the legal and other know-how present in Brussels by allowing specialists from various branches of law and business to sit as BIBC lay judges (see Section 4 below), thereby making their expertise available to the wider business community. ${ }^{16}$

- Thirdly, there are also important economic benefits to be gained. Attracting to or keeping in Belgium international trade disputes that would otherwise be settled by a foreign court will generate economic added value. In addition to high-quality and knowledgeintensive jobs in the legal sector, there will also be knock-on benefits for other parts of the economy such as the hotel sector. In the UK, for example, the legal sector contributed an estimated £25.7 billion overall to the economy in $2017 .{ }^{17}$ Once up and running, it is estimated that the Netherlands Commercial Court will generate revenues of between $€ 60$ million and $€ 75$ million per annum. ${ }^{18}$ Understandably, Bel-

11. In 2017, the London Commercial Court was merged into the Business and Property Courts of England and Wales comprising specialist jurisdictions.

12. Singapore International Commercial Court.

13. Dubai International Finance Centre (DIFC) Courts.

14. Amendment of the Code of Civil Procedure and the Act on Court Fees in Civil Proceedings to make it possible for cases to be handled in English by the international commercial chambers of the Amsterdam District Court and the Amsterdam Court of Appeal. The establishment of the Netherlands Commercial Court was approved by the Dutch Parliament on 11 December 2018.

15. Protocole relatif à la procedure devant la chambre internationale du tribunal de commerce de Paris (Protocol relating to proceedings before the International Chamber of the Paris Commercial Court) and Protocole relatif à la procedure devant la Chambre Internationale de la Cour d'appel de Paris (Protocol relating to proceedings before the International Chamber of the Paris Court of Appeal).

16. These are referred to as the 'BIBC judges' (corresponding to the 'judges in the $B I B C^{\prime}$ in the legislation).

17. The legal services sector accounted for 370,000 jobs. See for example (i) https://www.thecityuk.com/research/legal-excellence-internationally -renowned-uk-legal-services-2017 (last visited on 1 December 2018) and also (ii) The Lord Chief Justice's Report 2017, at 29 (2017). The international appeal of the UK commercial courts is clear from the fact that in more than 70 per cent of the cases at least one of the parties was registered abroad. In 45 per cent of cases, both parties were based outside the UK. TheCityUK, Legal excellence internationally renowned - UK Legal Services 2017, at 27 (2017).

18. Raad voor de rechtspraak (Council for the Judiciary), Plan tot oprichting van de Netherlands Commercial Court, at 14 (2015). These social benefits are based on an assumption of around 125 cases per year, including 25 appeal cases. 
gium is keen to share in the anticipated economic rewards.

- Fourthly, by handing down fast, expert and final judgments, the BIBC should help to expand the expertise of the Belgian judiciary both nationally and internationally. The fact that all international business disputes will be handled by the BIBC should lead to specialisation. The idea is that companies will take their disputes to the BIBC not just because it is an English-speaking court but also owing to its general quality, speed and specialisation and the ease of enforcement. In this way the BIBC will help to achieve the overarching goal of enhancing the overall quality and attractiveness of the Belgian legal system for (in particular, foreign) investors. ${ }^{19,20}$

- Lastly, Brexit is also cited as a factor behind the timing of the court's creation. While the idea of an English-speaking business court predates the process of the UK leaving the European Union, ${ }^{21}$ the Belgian legislature expects this to result in an increase in the number of disputes. ${ }^{22}$ Whether Brexit will dent the popularity of UK courts and English law for resolving international business disputes will depend on the future arrangements for the recognition and enforcement of civil court judgments in the European Union. $^{23}$

19. The positive impact of an effective judiciary on the attractiveness of the investment climate has been extensively demonstrated in the literature. See for example (i) International Monetary Fund, Fostering Growth in Europe (2012); (ii) World Bank, World Development Report 2017: Governance and the Law, available at: http://www.worldbank.org/en/ publication/wdr2017 (last visited on 1 December 2018); (iii) OECD, 'What makes civil justice effective?', Economics Department Policy Notes, no. 18 (2013) and G. Palumbo, G. Giupponi, L. Nunziata \& J.S. Mora Sanguinetti, 'The Economics of Civil Justice: New Cross-Country Data and Empirics', OECD Economics Department Working Papers, no. 1060 (2013); and (iv) European Commission, The 2018 EU Justice Scoreboard (2018). Also see H. Eidenmuller, 'The Transnational Law Market, Regulatory Competition, and Transnational Corporations', 18/2 Indiana Journal of Global Legal Studies 707, at 714 (2011).

20. During the parliamentary debate on the Netherlands Commercial Court, reference was made to an undesirable reduction in social and legal standards, i.e. a 'race to the bottom', to attract international disputes. However, merely establishing an English-speaking business court does not prejudice substantive law. It can even be argued that, in fact, this leads to an improvement in the quality of substantive law by means of a 'race to the top'. Tweede Kamer der Staten Generaal (House of Representatives of the Dutch Parliament), '34761 Wijziging van het Wetboek van Burgerlijke Rechtsvordering en de Wet griffierechten burgerlijke zaken in verband met het mogelijk maken van Engelstalige rechtspraak bij de internationale handelskamers van de rechtbank Amsterdam en het gerechtshof Amsterdam', 6:3 (2017).

21. The French-speaking Bar (Avocats.be) advocated the establishment of an English-speaking chamber of the Brussels Commercial Court in an election memorandum in 2014. Presentation by Jean-Pierre Buyle, 'Verslag van de eerste lezing namens de commissie voor de Justitie'/'Rapport de la première lecture fait au nom de la commission de la Justice' (Report on the first reading on behalf of the Justice Committee), Parl. St./Doc. parl. (Parliamentary Documents): Kamer/Chambre (Belgian House of Representatives) 54, 3072/007, at 59.

22. "Brexit" and the resulting difficulties will lead to an exponential increase in the number of international trade disputes', Parl. St./Doc. parl. (Parliamentary Documents): Kamer/Chambre (Belgian House of Representatives) 54, 3072/001, at 5.

23. To emphasise the leading position of the UK courts and English law, the Lord Chief Justice stated that these would be unaffected by Brexit. The Lord Chief Justice's Report 2017, at 36, available at: https://
However, not everyone is convinced by these arguments. The establishment of the BIBC has provoked some controversy, with dissenting voices heard particularly among the Belgian judiciary. ${ }^{24}$ For example, an opinion issued by the High Council of Justice was highly critical of the Bill. ${ }^{25}$ The Council of State too published a very extensive opinion regarding the legislation.

Where appropriate, the criticism that has been levelled at the Bill will be addressed later in this article.

\section{The BIBC and the Belgian Constitution}

In contrast to the initiatives taken in the Netherlands ${ }^{26}$ and France, the Belgian legislature has decided not to establish an English-speaking chamber at an existing court. Having the BIBC as a stand-alone business court thus involves a more radical change to Belgium's legal architecture than was needed in those countries. ${ }^{27}$

www.judiciary.uk/publications/the-lord-chief-justices-report-2017 (last visited on 1 December 2018). Various other publications have also appeared underlining this: (i) The strength of English law and the UK jurisdiction and English law, available at: https:// www.judiciary.gov.uk/wp-content/uploads/2017/08/legaluk-strengthof-english-law-draft-4-FINAL.pdf (last visited on 1 December 2018), and (ii) UK courts and UK legal services after Brexit - the view beyond 2019, available at: http://www.chba.org.uk/news/brexit-memo (last visited on 1 December 2018); as regards the broad thrust of a future cooperation framework, see the UK government's position paper of 22 August 2017, HM Government, Providing a Cross-Border Civil Judicial Cooperation Framework: A Future Partnership (2017), available at: https://www.gov.uk/government/publications/providing-a-cross-

border-civil-judicial-cooperation-framework-a-future-partnership-paper (last visited on 1 December 2018).

24. 'Lettre ouverte des magistrats de la cour d'appel de Bruxelles', 1 December 2018, available at: o0.llb.be/file/5a218368cd7095d 1cd315c1b.pdf (last visited on 1 December 2018); 'Des magistrats de la cour d'appel de Bruxelles critiquent le projet de tribunal anglophone', La Libre (2017); A. Henkes, 'Over grensoverschrijdende fiscaliteit, andere internationale economische vraagstukken en de bijdrage van het Hof van Cassatie', Plechtige openingszitting van het Hof van Cassatie van België (Solemn opening session of the Belgian Supreme Court) 29 (2018), available at: https://justitie.belgium.be/sites/default/files/ downloads/mercuriale2018_nl_site.pdf (last visited on 1 December 2018); P. Havaux, 'Tribunal Cinq Étoiles', 33 Le Vif 22 (2018). The Minister of Justice was also asked various parliamentary questions in the months leading up to the establishment of the BIBC, specifically (i) Question no. 2438 from member of parliament Jean-Jacques Flahaux on 2 February 2018 (Fr.) to the Minister of Justice) and the Minister's answer, 54:149 Questions Réponses - Vragen Antwoorden 310, 21 March 2018; (ii) Question no. 25437 from member of parliament Georges Gilkinet to the Minister of Justice regarding 'the Bill establishing the Brussels International Business Court', 55:COM 897 Compte Rendu Intégral - Integraal Verslag 21, 16 May 2018.

25. Hoge Raad voor de Justitie/Conseil supérieur de la Justice (Belgian High Council of Justice), 'Avis d'office : Avant-projet de loi instaurant la Brussels International Business Court' (2018), available at: http:// www.csj.be/fr/search/apachesolr_search?filters=type \%3Apublication (last visited on 1 December 2018).

26. This involves using English in the international commercial chambers of the existing Amsterdam District Court and the Amsterdam Court of Appeal, and therefore does not entail the establishment of a new court.

27. The name rechtbank van koophandel/tribunal de commerce ('commercial court') was abolished by the Act of 15 April 2018 on company law reform, published in the Belgisch Staatsblad/Moniteur belge (Belgian 
The BIBC must comply with the relevant provisions of the Belgian Constitution. In its opinion, the Council of State essentially applies a three-pronged test. The first constitutional test relates to the designation of the BIBC as a state court. The second concerns its compliance with the rules on language use. Thirdly, the Council examines compliance with the principle of equality.

\subsection{State Court}

To assess whether the BIBC complies with Belgium's constitutional provisions, the first aspect to consider is the nature of the disputes. This is a key factor in the division of labour between the judiciary and the administrative courts. ${ }^{28}$ The BIBC will settle disputes surrounding civil, subjective rights. As these are the sole responsibility of the judiciary, ${ }^{29}$ the BIBC must comply with the relevant constitutional provisions applicable to the judiciary, not those covering administrative courts.

The second factor is how the BIBC is established. The establishment of a new court requires the promulgation of a law: this legal principle is met in so far as the creation of the BIBC is enshrined in legislation..$^{30}$ The legislature also reserves the right to regulate the organisation and competence of (business) courts, as under the Belgian Constitution it is possible to set up various types of business court with their own specific rules relating to, for example, the language of the proceedings, territorial jurisdiction ${ }^{31}$ and composition.

Finally, the ban on occasional courts must be respected. To avoid arbitrariness and discrimination, it is not permitted to establish ad hoc courts to rule on individual cases. ${ }^{32}$ Given its clear delimitation of competences (see Section 5 below), applicable to an unspecified number of cases, the Council of State concludes that the BIBC is not in breach of this ban. ${ }^{33}$

Official Gazette) of 27 April 2018, which largely came into force on 1 November 2018, and replaced by ondernemingsrechtbank/tribunal de l'entreprise ('business court'). Art. 157 of the Belgian Constitution continues to use the term rechtbank van koophandel/tribunal de commerce ('commercial court') in the generic sense. Memorie van Toelichting/Exposé des motifs (Explanatory Memorandum), Parl. St./Doc. parl.: Kamer/Chambre (Belgian House of Representatives) 54, $3072 / 001$, at 54 . For the reader's convenience, the term business court is used systematically below.

28. This relates to the distinction, within the category of subjective rights, between civil and political rights. Disputes about civil rights fall within the exclusive competence of the courts, whereas disputes regarding political rights can be assigned to administrative courts. W. Verrijdt, 'Commentaar bij artikel 144 GW', 39 OAPR (2015), at 85; A. Alen and K. Muylle, Compendium van het Belgisch Staatsrecht - syllabusuitgave (2012), at 294-8.

29. Art. 144(1) of the Belgian Constitution.

30. C. Berx, 'Commentaar bij artikel 146 GW', 9 OAPR (1999), at 27.

31. The BIBC will be based in Brussels. Under the proposed Art. 1385quaterdecies/10 of the Belgian Judicial Code, the BIBC may convene wherever it deems appropriate for its members to deliberate; for witnesses, experts or the parties to be heard; or for goods, other objects or documents to be examined.

32. B. Dalle, D. Keynaerts, W. Pas, J. Theunis \& W. Verrijdt, Duiding Federale Staatsstructuur (2018), at 187.

33. Proposed Art. 73(3) of the Belgian Judicial Code. This means it is not a 'temporary or ad hoc court to which specific individual disputes are referred.' Opinion of the Belgian Council of State, Parl. St./Doc. parl. (Parliamentary Documents): Kamer/Chambre (Belgian House of Representatives) 54, 3072/001, at 103.

\subsection{Language Use}

The second test relates to the constitutional provisions on language use. Belgian case law tends to adopt a pragmatic stance towards the use of English. ${ }^{34}$ In this light, without recognising English as an official language, the Council of State tolerates public services - and therefore also the judiciary, of which BIBC forms part - using English 'in so far as the use of the official language or official languages proves impossible due to the nature of the case or in so far as the services' needs or general interest requirements make the use of other languages necessary. ${ }^{35}$

Accordingly, the Council of State considers the following requirements to apply: (i) sufficient objective elements in a dispute indicate the use of English, and (ii) this does not affect the priority of the languages of the respective language area. Now that its competences have been clearly delimited, the BIBC meets the first requirement. ${ }^{36}$ The condition establishing the priority of the language or languages of the respective language area is also unaffected given that users of the official languages are not obliged to conduct English-speaking proceedings before the BIBC. The parties' consent is always required (see Section 5 below). ${ }^{37}$

However, problems could potentially arise with regard to third parties, as they would not have agreed to English-language proceedings. Third-party opposition proceedings will therefore still be possible in Dutch, French or German. ${ }^{38}$ This will avoid a situation where-

34. Since the entry into force of the Act of 25 May 2018 on the reduction and redistribution of the workload within the judicial system, published in the Belgisch Staatsblad/Moniteur belge (Belgian Official Gazette) of 30 May 2018, language use in court cases is no longer a matter of public policy. Arts. 794, 861 and 864 of the Belgian Judicial Code are now rules prescribed on pain of nullity. This pragmatic change makes the system more flexible, allowing the court to prevent the annulment of an irregular act by making good the disadvantage incurred by a party. Memorie van Toelichting/Exposé des motifs (Explanatory Memorandum), Parl. St./Doc. parl. (Parliamentary Documents): Kamer/Chambre (Belgian House of Representatives) 54, 2827, at 27-8; K. Wagner, 'De sanctieregeling in de taalwet van 1935: Quousque tandem abutere patientia nostra?', 2010(3) Revue de Droit Commercial Belge - Tijdschrift voor Belgisch Handelsrecht (RDC - TBH) 234 (2010).

35. Opinion of the Belgian Council of State, Parl. St./Doc. parl. (Parliamentary Documents): Kamer/Chambre (Belgian House of Representatives) 54, 3072/001, at 107-8 and also footnote 34.

36. The preliminary draft stated that a dispute was international 'if the parties have explicitly agreed that the subject of the dispute relates to more than one country'. Therefore, all the parties needed to do for the BIBC to be competent was classify a dispute as international. Such a general formulation provided an insufficiently objective description of the BIBC's competence.

37. Opinion of the Belgian Council of State, Parl. St./Doc. parl. (Parliamentary Documents): Kamer/Chambre (Belgian House of Representatives) 54, 3072/001, at 110 .

38. Third-party opposition is an extraordinary legal remedy whereby a person who is not party to a dispute and who considers himself prejudiced by a judgment can file an objection to this ruling. It owes its existence to the need for a third party to have a legal remedy at his disposal to challenge a judgment that adversely affects his rights. In this light, the Bill (Art. 20) makes the common law procedure set out in Arts. 1122-1131 of the Belgian Judicial Code applicable; K. Wagner, 'Derdenverzet', Algemene Praktische Rechtsverzameling (2004), at 1. This is different from arbitration, where on the basis of Art. 1686 of the Belgian Judicial Code no third-party opposition is possible. Wagner (2004), at 59 . 
by third parties who do not speak English do not correctly understand the scope of a BIBC judgment and would therefore be unable to actually exercise their right to third-party opposition. ${ }^{39}$ The possibility of filing the third-party opposition in Dutch, French or German only applies to the opposing party, whose documents will be translated into English and for whose benefit the documents of the other parties to the proceedings will be translated from English. Apart from this, the proceedings will remain completely in English. ${ }^{40}$ Given the anticipated exceptional nature of third-party opposition, this pragmatic solution seems admissible and does not appear, a priori, to represent a violation of the Belgian Constitution.

\subsection{Equality Principle}

The third factor is that proceedings before the BIBC must comply with the equality principle. ${ }^{41}$ Where different procedural rules are applied, there must be reasonable justification. Proceedings in English before the BIBC must not offer benefits that are disproportionate to those enjoyed by parties who submit an international business dispute to a conventional business court for resolution. Parties not opting for such proceedings must not be disadvantaged. ${ }^{42}$

Differences in treatment as a result of differing court procedures are, of course, commonplace. However, if parties intentionally choose a specific court in advance, there is no breach of the equality principle. ${ }^{43}$ Moreover, the legislature has some room for manoeuvre in regulating the actual organisation and the competence of business courts. ${ }^{44}$ The procedural differentiation applying to the BIBC is based on an objective delimitation of competences, meaning that it also passes this test a priori ${ }^{45}$

39. The legislature considers it highly unlikely that an interested third party would not have a command of English, given the nature of the disputes on which the BIBC will be ruling, but the abolition of third-party opposition proceedings against a BIBC judgment would be in direct breach of Arts. 10 and 11 of the Belgian Constitution, according to the Opinion of the Belgian Council of State, Parl. St./Doc. parl. (Parliamentary Documents): Kamer/Chambre (Belgian House of Representatives) 54, 3072/001, at 137.

40. This restriction is justified by the proportionality principle. The opposing party may also use his own language at any hearings. In that case simultaneous interpretation will be arranged. The interpretation costs will be borne by the Belgian State and will not be included in the increased registration fee paid by the parties. See the proposed Art. 2/1(2) of the Belgian Act of 15 June 1935 on the use of languages in judicial proceedings.

41. Arts. 10 and 11 of the Belgian Constitution.

42. On this point, the Bill has been amended from the preliminary draft examined by the Belgian Council of State.

43. The Belgian Constitutional Court has confirmed that this does not constitute a breach of the equality principle, while the same applies to the differences between state court case law and arbitration. Belgian Constitutional Court of 16 February 2017, Case no. 21/2017

44. The constitutional provision merely prevents commercial courts from being abolished or being deprived of their essential powers.

45. Memorie van Toelichting/Exposé des motifs (Explanatory Memorandum), Parl. St./Doc. parl. (Parliamentary Documents): Kamer/Chambre (Belgian House of Representatives) 54, 3072/001, at 8.

\section{Composition}

A panel will be formed for every case brought before the BIBC. ${ }^{46}$ To properly understand its composition, the three-way distinction between the Chairman, the panel chairman and the judges must always be borne in mind.

\subsection{Chairman/Chairmen of the BIBC}

\subsubsection{Role and Tasks}

The BIBC will be headed by a Chairman. ${ }^{47}$ The Chairman will always be a professional judge from the Brussels Court of Appeal who sits in the Market Court. ${ }^{48}$ The Market Court has exclusive jurisdiction over various matters and is the central forum for appeals against the decisions of administrative authorities such as the Belgian Competition Authority and the Financial Services and Markets Authority.

Like the chiefs of staff at other business courts, the Chairman will be appointed by the King (i.e. the government) based on a reasoned nomination by the High Council of Justice, an independent body charged with selecting judges. ${ }^{49,50}$ The BIBC chairmanship will not be a full-time position, being combined with the role of a judge at the Market Court. ${ }^{51}$

46. For each case registered on the roll, the Chairman will establish a panel as soon as possible, and, in any case, within a month. The panel's composition is then communicated to the parties. The one-month period starts with the registration on the roll. Proposed Art. 85/1(3) of the Belgian Judicial Code.

47. Like the Belgian Constitutional Court, the BIBC will have two Chairmen, one from the Dutch-speaking register and the other from its Frenchspeaking counterpart, who hold the presidency for alternating one-year periods. Where the 'Chairman' is referred to in the rest of this article, the serving Chairman at the time is meant.

48. The Market Court is not a stand-alone court but a section of the Brussels Court of Appeal. Art. 59 of the Belgian Act of 25 December 2016 to amend the legal status of prisoners and the supervision of prisons, and containing various provisions related to the judicial authorities, published in the Belgisch Staatsblad/Moniteur belge (Belgian Official Gazette) of 30 December 2016: 'At the Brussels Court of Appeal there are also chambers for market affairs, whose competence is established by law. These chambers form a section called the "Market Court".' Also see $M$. Bosmans, 'Het Marktenhof blies zijn eerste verjaardagskaarsje uit ...', 13/1 Competitio - Belgian Competition Quarterly 66 (2018).

49. In a preliminary draft, the Chairman of the BIBC was to be 'appointed by the Minister of Justice'. After severe criticism from the High Council of Justice, the Bill was amended. Accordingly, the proposed Art. 58 bis(2) of the Belgian Judicial Code was amended to also regard the BIBC Chairmanship as a chief of staff (korpschef/chef de corps) mandate. Hoge Raad voor de Justitie/Conseil supérieur de la Justice (Belgian High Council of Justice), 'Avis d'office : Avant-projet de loi instaurant la Brussels International Business Court' (2018), available at: http:// www.csj.be/fr/search/apachesolr_search?filters=type \%3Apublication (last visited on 1 December 2018). This adjustment ensures compliance with Art. 151 of the Belgian Constitution.

50. Under this Article, the Chairmen will be appointed by a two-thirds majority of votes following a reasoned nomination by the High Council of Justice's Nomination and Appointment Committee in accordance with the detailed rules laid down by law and after considering the qualifications and aptitude of the candidates.

51. The holding of multiple judicial offices is generally not allowed in Belgium. Exceptions are possible where laid down by law, as in the case of the Bill establishing the BIBC. Memorie van Toelichting/Exposé des motifs (Explanatory Memorandum), Parl. St./Doc. parl. (Parliamentary Documents): Kamer/Chambre (Belgian House of Representatives) 54, 3072/001, at 16 
The Chairman's main task is to establish the panel for every new case. Unlike in arbitration, parties will not be able to choose their judge, ${ }^{52}$ nor will they know the panel's composition in advance. In line with European and international legal practice, when assigning cases, the Chairman will consider objective criteria such as (i) internal administrative requirements, (ii) the fair allocation of cases, (iii) judges' availability, and (iv) judges' special expertise..$^{53}$

In addition, the Chairman will be responsible for disciplinary action against BIBC judges,${ }^{54}$ will deal with substitution requests ${ }^{55}$ and perform financial oversight of expense statements. ${ }^{56}$

The disciplinary options for these judges will differ from those for lay judges at a conventional business court. ${ }^{57}$ Specifically, for BIBC judges only one disciplinary sanction is available, namely the early termination of their duties. ${ }^{58}$ This is justified by the fact that some of the judges may be specialists from outside Belgium, making a more complex disciplinary procedure inappropriate. ${ }^{59}$ In the case of professional judges/panel chairmen, the Chairman will be able to launch conventional disciplinary proceedings for offences committed in the performance of their duties at the BIBC. ${ }^{60}$

Special arrangements will also apply to the substitution of panel members. Specifically, if the member whose substitution has been requested does not withdraw from the panel, the request will be assessed by the Chairman and the other BIBC panel member(s) whose substitution

52. This would be a violation of Art. 13 of the Belgian Constitution.

53. Proposed Art. 85/2(3) of the Belgian Judicial Code. After severe criticism from both the Council of State and the High Council of Justice, it is now expressly stated that the Chairman must explicitly take objective criteria into account when establishing the panel. See Hoge Raad voor de Justitie/Conseil supérieur de la Justice (High Council of Justice), $n .{ }^{*}$, at 4, and Opinion of the Council of State, Parl. St./Doc. parl. (Parliamentary Documents): Kamer/Chambre (Belgian House of Representatives) 54, 3072/001, at 126, alluding to case law from the European Court of Human Rights and reports from the Venice Commission.

54. Proposed Art. 85/3(3) of the Belgian Judicial Code.

55. Proposed Art. 1385quaterdecies/7(3) of the Belgian Judicial Code

56. Proposed Art. 1385quaterdecies/22(2) of the Belgian Judicial Code.

57. Business court judges who neglect their official duties or whose conduct does not befit the dignity of their office are liable to disciplinary sanctions under Arts. 404 to 427 of the Belgian Judicial Code. Under Art. 412 (1)e of the Belgian Judicial Code, the disciplinary authority for business court judges is the Chairman of the relevant commercial court. The proposed Art. 85/3 of the Belgian Judicial Code states that any BIBC judges neglecting their official duties or whose conduct does not befit the dignity of their office may be removed from office by the disciplinary court at the request of the serving Chairman of the BIBC. The disciplinary proceedings will be held in Dutch and French, but the disciplinary board may, at the request of the individual concerned, order that interpreters be used and that the ruling or judgment be translated into English.

58. Proposed Art. 85/3(3) of the Belgian Judicial Code.

59. Memorie van Toelichting/Exposé des motifs (Explanatory Memorandum), Parl. St./Doc. parl. (Parliamentary Documents): Kamer/Chambre (Belgian House of Representatives) 54, 3072/001, at 19.

60. The proposed Art. 412(1)(1)h of the Belgian Judicial Code enables the serving Chairman of the BIBC to launch disciplinary proceedings against panel chairmen

61. Proposed Art. 1385quaterdecies/7(2) of the Belgian Judicial Code. At an arbitral tribunal, the parties can agree on the procedure for substituting an arbitrator. In the absence of such agreement and if an arbiter has not been requested. ${ }^{61,62}$ The Council of State has warned that this closeness between the panel member facing such a request and the other members may give rise to doubts about the independence and impartiality of the decision reached. ${ }^{63}$ The legislature does not share this concern, believing that the judge(s) sitting on the BIBC panel will be able to form a completely objective judgment regarding a fellow member's substitution. An additional safeguard is provided by the fact that the request is assessed by a college that includes the Chairman. ${ }^{64}$

\subsubsection{Observations}

The Chairman's role and tasks are those of a chef de corps (chief of staff) with responsibility for administrative matters. This prompts a number of observations.

Firstly, the Market Court, unlike the BIBC, is not a stand-alone court. Established in 2016, it forms a separate section of the Brussels Court of Appeal. However, it is currently having trouble filling all its vacancies. ${ }^{65}$ Under these circumstances, the question arises whether it is wise to assign an additional workload to its members. In the initial period, the Chairman may well have to spend a considerable amount of time getting the BIBC onto the international radar. ${ }^{66}$

Secondly, it is not clear why Market Court judges would necessarily be more familiar with (international) trade law than a business court judge. The legislature justifies this privileged relationship on the grounds of a need for continuity and a central location in Brussels - given the varying composition of panels and the fact that lay judges may also come from abroad - as well as the special expertise in economic law sensu lato that Market Court judges possess. ${ }^{67}$ This justification seems questionable from the perspective of the principle of equality of all candidate Chairmen. ${ }^{68}$

does not voluntarily withdraw from his/her role following a substitution request, under Art. 1687(2) of the Belgian Judicial Code the case will be referred to the court of first instance for non-institutional arbitration with the possibility of appeal. The substitution procedure for conventional judges is set forth in Art. 828ff. of the Belgian Judicial Code. Additional grounds for substitution for business court judges are provided for in Art. 829 of the Belgian Judicial Code.

62. The fifteen-day period within which the parties can request that the judges be replaced starts upon notification of the establishment of the panel.

63. Opinion of the Belgian Council of State, Parl. St./Doc. parl. (Parliamentary Documents): Kamer/Chambre (Belgian House of Representatives) 54, 3072/001, at 146

64. Memorie van Toelichting/Exposé des motifs (Explanatory Memorandum), Parl. St./Doc. parl. (Parliamentary Documents): Kamer/Chambre (Belgian House of Representatives) 54, 3072/001, at 30. In the case of international arbitration too, the arbitral tribunal itself will decide.

65. M. Bosmans, 'Het Marktenhof blies zijn eerste verjaardagskaarsje uit $\therefore$ 13(1) Competitio - Belgian Competition Quarterly 66 (2018).

66. Is external representation a task for the Chairman, or is this the responsibility of the chief of staff of the Brussels Court of Appeal?

67. Memorie van Toelichting/Exposé des motifs (Explanatory Memorandum), Parl. St./Doc. parl. (Parliamentary Documents): Kamer/Chambre (Belgian House of Representatives) 54, 3072/001, at 15.

68. Presentation by Magali Clavie, President of the High Council of Justice, 'Verslag van de eerste lezing namens de Commissie voor de Justitie'/ 'Rapport de la première lecture fait au nom de la commission de la Justice' (Report on the first reading on behalf of the Justice Committee), Parl. St./Doc. parl. (Parliamentary Documents): Kamer/Chamber (Bel- 
Thirdly, the question arises as to how useful 'special expertise' is as an assignment criterion. A high level of specialisation is a prerequisite for being included in the pool of potential BIBC panel chairmen and judges. ${ }^{69}$ Even the Belgian High Council of Justice seems unconvinced by the proposed clarifications regarding case distribution. It advocates that cases be assigned according to a special set of rules from which the Chairman may deviate only on the basis of objective criteria. ${ }^{70}$

Finally, it remains unclear why the formal language requirements are deemed superfluous for the Chairman but not for the judges and panel chairmen. The legislature points to the position as belonging to the domain of internal administrative law and believes that knowledge of the field is also implicit proof of a knowledge of English. ${ }^{71}$ Obviously, any Chairman must be fluent in English; otherwise how could he or she promote the BIBC to the international business community or communicate easily with English-speaking judges? Due consideration should be given to this issue when assessing candidate Chairmen.

\subsection{Panel Chairman}

\subsubsection{Role and Tasks}

The chairman of a BIBC panel must not be confused with the Chairman of the BIBC. In the legislation this distinction is made explicit in French, for example by writing the former without an initial capital and the latter with one: président as opposed to Président. ${ }^{72}$

For every case that is brought before the BIBC, a panel chaired by a Belgian professional judge will be established. ${ }^{73} \mathrm{He}$ or she will be selected by the Chairman from those Belgian judges with the appropriate fluency in English and knowledge of international trade law. ${ }^{74}$ This setup will enable expertise to be mobilised from throughout Belgium and brought together at the BIBC. The justices at the Hof van Cassatie/Cour de Cassation

gian House of Representatives) 54, 3072/007:4, which says that the preparatory works provide inadequate justification for why Chairmen can come only from the Market Court. Interestingly, the preparatory works speak of the economic expertise of some Market Court judges. Art. 207(3)(4) of the Belgian Judicial Code states that: ' [...] judges at the Brussels Court of Appeal, who have priority for the Market Court, shall have at least fifteen years' useful professional experience that demonstrates specialist knowledge of economic, financial or market law.'

69. The Council of State had also pointed this out in its opinion.

70. Presentation by Magali Clavie, President of the High Council of Justice, 'Verslag van de eerste lezing namens de Commissie voor de Justitie'/ 'Rapport de la première lecture fait au nom de la commission de la Justice' (Report on the first reading on behalf of the Justice Committee), Parl. St./Doc. parl. (Parliamentary Documents): Kamer/Chambre (Belgian House of Representatives) 54, 3072/007, at 5.

71. Memorie van Toelichting/Exposé des motifs (Explanatory Memorandum), Parl. St./Doc. parl. (Parliamentary Documents): Kamer/Chambre (Belgian House of Representatives) 54, 3072/001, at 16.

72. However, this is not always systematically followed. See, for example, the proposed Art. 58bis(2) of the Belgian Judicial Code, where 'président de la BIBC' ('chairman of the BIBC') is used, without an initial capital, although it is clear that the Chairman is meant rather than the panel chairman.

73. Proposed Art. 85/1(1) of the Belgian Judicial Code.

74. Taking into account the objective criteria in the proposed Art. 85/2(3) of the Belgian Judicial Code.
(Supreme Court) cannot apply. This is justified by the fact that parties could decide to appeal to the Supreme Court against BIBC judgments.

The successful candidates for the panel chairmanship will be added to a list 'after publication of the vacancy, submission of their applications and the performance of an aptitude test by a selection committee'. This will establish a pool of specialist, experienced professional judges who can then be used for the BIBC. This list will be valid for five years and may be renewed. ${ }^{75}$

The panel chairman's main task is to chair the BIBC panel. ${ }^{76} \mathrm{He}$ or she will be responsible for steering the session along the right lines. Decisions of the panel will be taken by a simple majority vote of its members. The panel chairman will decide on the procedure alone only if authorised to do so by all the panel members. ${ }^{77}$ This is a limited exception to the collegiality rule that otherwise applies to the panel.

\subsubsection{Observations}

The panel chairman's role and competences give rise to the following observations.

First, criticism has been levelled at the selection method adopted. Instead of nomination by the High Council of Justice, the recruitment, selection and reasoned nomination of panel chairmen will be undertaken by a selection committee, prompting the High Council of Justice to question their independence. To address this criticism, the Bill further clarifies the composition of the selection committee. ${ }^{78}$ Reference is also made to the fact that the panel chairmanship is an occasional assignment that is

75. Proposed Art. 85/2 of the Belgian Judicial Code.

76. For this reason, the chairmanship of the panel is equated with a special mandate within the meaning of the proposed Art. 58bis(4) of the Belgian Judicial Code. Examples include the mandates of investigating judge, family and juvenile court judge and judge at the sentence enforcement court. No mention is made of the consent of the individual concerned to his or her actual appointment by the Chairman.

77. Proposed Art. 1385quaterdecies/18 of the Belgian Judicial Code.

78. The choice of a selection committee has been heavily criticised, owing to fears that it could compromise the judges' independence. To address this, the Bill clarifies the composition of the selection committee. Thus, under the proposed Art. 85/3(4) of the Belgian Judicial Code, the selection committee would consist of: (i) the Chairmen of the BIBC, (ii) two judges or emeritus judges from courts of appeal, one from the Dutchspeaking register and the other from the French-speaking register, appointed by the Belgian College of Courts and Tribunals, and (iii) two professors teaching international trade law at university level, one in the Flemish Community and the other in the French Community, appointed by the Belgian Federal Minister of Justice. The committee would be chaired by the serving Chairman of the BIBC and would make decisions by an absolute majority of members present. The Belgian High Council of Justice deems this inadequate and considers that the appointment of the professors by the Minister of Justice instead of the High Council is unjustifiable. It would also prefer that judges be appointed by the High Council rather than by the College of Courts and Tribunals. Presentation by Magali Clavie, President of the High Council of Justice, 'Verslag van de eerste lezing namens de Commissie voor de Justitie'/'Rapport de la première lecture fait au nom de la commission de la Justice' (Report on the first reading on behalf of the Justice Committee), Parl. St./Doc. parl. (Parliamentary Documents): Kamer/Chambre (Belgian House of Representatives) 54, 3072/007, at 58. The adoption of Amendment no. 5 tabled by Sonja Becq and others (Parl. St./Doc. parl. (Parliamentary Documents): Kamer/Chambre (Belgian House of Representatives) 54, $3072 / 002$, at 7) means that emeritus judges can also sit on the selection committee. Furthermore, the professors will be appointed by the King, 
open only to professional judges who have already been appointed following nomination by the High Council of Justice. As a result, the High Council of Justice does not have to step in (again) when it comes to exercising a special mandate of this kind. ${ }^{79}$

Secondly, there have been warnings about the negative impact on the work of other courts. The exact number of potential panel chairmen is not known, and the legislation provides no clarification on this. As judges will be taken away from ongoing cases to serve as panel chairmen, there are fears about the impact on the work of other courts. This is a particularly pertinent issue in the case of panel chairmen from the Brussels Court of Appeal, which already has Belgium's longest case processing times. ${ }^{80}$ The Bill envisages financial compensation for the entity supplying the panel chairman (see Section 7.1 below). Whether this will be enough to neutralise the impact on the work of other courts and tribunals and their processing times remains to be seen.

\subsection{BIBC Judges}

\subsubsection{Role and Tasks}

The lay judges, or 'judges in the BIBC', as the legislation calls them, are the third category in the BIBC's composition. ${ }^{81}$ They are chosen from a list of international trade law specialists from Belgium and abroad who can demonstrate sufficient knowledge of English. There is no requirement for candidates to hold a law degree. The required level of knowledge of the judges, who must be specialists, will be higher than for the panel chairman, who needs to have sufficient knowledge of international trade law. For these judges, the legislature is seeking top experts in international trade law with English-language skills. Lawyers, academics and company legal advisers from both Belgium and abroad will be eligible, and no age limit will apply.

As with the panel chairmen, the list of judges will be valid for a five-year period. They will form a pool of qualified lay judges for the BIBC, on which the Chairman can draw. The exact length of the lists is not specified. As it is difficult to accurately estimate how many

by a decree enacted following deliberation in the Federal Council of Ministers, and not by the Minister of Justice, as previously envisaged.

79. This is in contrast to the Chairmen who, because they are being appointed as chiefs of staff, do indeed have to be nominated by the High Council of Justice: 'Verslag van de eerste lezing namens de Commissie voor de Justitie'/'Rapport de la première lecture fait au nom de la commission de la Justice' (Report on the first reading on behalf of the Justice Committee), Parl. St./Doc. parl. (Parliamentary Documents): Kamer/Chambre (Belgian House of Representatives) 54, 3072/007, at 18.

80. The average period between registration and final judgment is 885 days, according to College van de hoven en rechtbanken/Collège des cours et tribunaux (College of Courts and Tribunals), 'Les statistiques annuelles des cours et tribunaux : Données 2017' (2018), at 37, available at: https://www.rechtbanken-tribunaux.be/fr/telechargements/ cours-dappel-affaires-civiles-2017-0 (last visited on 1 December 2018).

81. The legislature explicitly wanted to use the English term 'judge in the $B I B C$ ' in the authentic Dutch and French versions of the Bill: 'Verslag van de tweede lezing namens de Commissie voor de Justitie'/'Rapport de la deuxième lecture fait au nom de la commission de la Justice' (Report on the second reading on behalf of the Justice Committee), Parl. St./Doc. parl. (Parliamentary Documents): Kamer/Chambre (Belgian House of Representatives) 54, 3072/010, at 4. cases the BIBC will handle in an average year, the preparatory works refer to 'a sufficient but not unduly large' number of individuals. The legislature wants there to be enough flexibility to meet unpredictable and fluctuating demand. ${ }^{82}$

The names of the panel chairmen and judges with their titles and capacities will be published in the Belgian Official Gazette. ${ }^{83}$ They may even be published internationally, with a view to promoting the BIBC's image and reputation outside Belgium.

The judges will not be required to sit a standardised language test. The legislature is confident that possessing the required expertise in international trade law presupposes a good command of English and that the selection committee will monitor this. It is true that subjecting native speakers from abroad to a Belgian standardised language test does seem excessive. There are other ways in which judges can prove their language skills, such as submitting a diploma from an educational institution in which English is the language of instruction. ${ }^{84}$

\subsubsection{Observations}

The following reservations arise concerning the role and tasks of judges.

Firstly, in terms of the appointment method for judges, a parallel may be drawn with the appointment of lay judges at conventional business courts. These lay judges, or 'business court judges', are nominated for appointment by the organisations representing employers, employees and the self-employed for renewable five-year terms. ${ }^{85}$ Here too, there is no involvement by the High Council of Justice.

Secondly, it is only right and proper that lay judges, by the nature of their role, should not have the guarantee of an appointment for life. However, this should not prejudice their independence. During their term of office, the constitutional guarantees preventing the removal or transfer of judges will continue to apply. ${ }^{86}$ Furthermore, their independence arises from the fact that they hold other independent positions and the role of judge is not their main professional activity. As a result, they need not fear any negative consequences of their decisions because such consequences will, as a rule, have no effect on their professional and material status. ${ }^{87}$

82. Opinion of the Belgian Council of State, Parl. St./Doc. parl. (Parliamentary Documents): Kamer/Chambre (Belgian House of Representatives) $54,3072 / 001$, at 118 . Nor is the number of lay judges at conventional business courts laid down by law.

83. Proposed Art. 85/2(6) of the Belgian Judicial Code.

84. Memorie van Toelichting/Exposé des motifs (Explanatory Memorandum), Parl. St./Doc. parl. (Parliamentary Documents): Kamer/Chambre (Belgian House of Representatives) 54, 3072/001, at 18.

85. Arts. 202, 204 and 216 of the Belgian Judicial Code.

86. Arts. 152(2) and (3) of the Belgian Constitution set forth the key safeguards for judges' independence, namely that they cannot be removed from their posts except by a court decision and cannot be transferred except by their appointment to a new position by the High Council of Justice and with their consent. The authors of the Constitution thereby aimed to ensure that forced transfers could not be used as a means of pressure.

87. Opinion of Advocate General Szpunar delivered on 8 April 2014, C-377/13, Ascendi, ECLI:EU:C:2014:246, point 47. 
Thirdly, the BIBC will also apply foreign law when requested to do so. It is therefore an advantage to have a good mix of experts and lawyers with common and civil law backgrounds. ${ }^{88}$ In this regard the BIBC will enjoy a comparative advantage over, for example, the Netherlands Commercial Court, which is open only to Dutch professional judges. As there is no requirement for lay judges to have Belgian citizenship, it will be possible to attract high-quality profiles from a range of legal traditions and very specific sectors of activity, such as energy and financial services.

Fourthly, as the judges are not required to know Dutch or French, the key Belgian legislation must also be available in English. Thus, a certified English translation of, for instance, the new Belgian Companies and Associations Code, commercial law or other key economic and financial legislation may enhance its international appeal. ${ }^{89}$ By the same token, it is self-evident that there should be an original English translation of the Act establishing the BIBC. ${ }^{90}$

\subsection{Registry}

Owing to expected fluctuations in its workload, the BIBC will initially not have its own registry and will use the registry of the Brussels Court of Appeal instead.

A pool of registrars with a sufficient, formally attested knowledge of English will be established within the Brussels Court of Appeal. ${ }^{91}$ Such registrars will need to be used only for necessary tasks such as preparing and checking legislation or correspondence. Other registry tasks may also be performed by registrars with little or no command of English. ${ }^{92}$

Depending on the workload, a permanent registry may be established in the longer term. In the current architecture, two court chiefs of staff will have to share a registry without any mechanism for determining priority. When the Council of State pointed this out, the legislature explained that 'there is no doubt that the First Chairman of the Brussels Court of Appeal and the President [Chairman] will come to an understanding.' There is some concern among the Brussels Bar that the establishment of the BIBC will aggravate the very difficult

88. This is in contrast to the Singapore International Commercial Court (SICC), where most of the judges have a background in common law.

89. Translations of France's main legislative codes are provided for information purposes, available at: https://www.legifrance.gouv.fr/ Traductions/Liste-des-traductions-Legifrance (last visited on 1 December 2018).

90. An official English translation is planned: Amendment no. 13 by Sonja Becq and others, Parl. St./Doc. parl. (Parliamentary Documents): Kamer/Chambre (Belgian House of Representatives) 54, 3072/002, at 18. However, the Belgian Council of State emphasised in its supplementary opinion on Amendment nos. 1-14 that such English translations have no official status: Opinion of the Belgian Council of State, Parl. St./Doc. parl. (Parliamentary Documents): Kamer/Chambre (Belgian House of Representatives) 54, 3072/003, at 8

91. Proposed Art. 164 of the Belgian Judicial Code. This makes reference to the Common European Framework of Reference (CEFR) and the required level.

92. Memorie van Toelichting/Exposé des motifs (Explanatory Memorandum), Parl. St./Doc. parl. (Parliamentary Documents): Kamer/Chambre (Belgian House of Representatives) 54, 3072/001, at 20. staffing situation at the Brussels Court of Appeal, to the detriment of court users. ${ }^{93}$

Will the registry also be responsible for the international publication of BIBC judgments and their availability online? The legislation provides no clarification regarding this task, or how and when it should be performed. It is vital that BIBC decisions are made available quickly and electronically if the court is to build up an international reputation.

\section{Competence}

Based in Brussels, the BIBC will be competent for the whole of Belgium. ${ }^{94}$ This distinguishes it from other business courts whose territorial jurisdiction is limited to a specific judicial district.

The BIBC will hear international disputes at first and last instance between companies that do not fall under the exclusive jurisdiction of other courts. Bankruptcy proceedings, for example, will continue to fall within the exclusive competence of Belgium's conventional business courts. They cannot be brought before the BIBC. 95

The BIBC will be competent for private law disputes arising from both contractual and non-contractual relationships. There will be no quantitative threshold for the value of disputes that can be brought before the BIBC. ${ }^{96}$ In case of dispute, the BIBC itself will decide whether it is competent. ${ }^{97}$

Three cumulative conditions must be fulfilled for the BIBC to be competent.

\subsection{Consent}

All proceedings will be brought before the BIBC on a voluntary basis. The consent of all parties must be based on a previously concluded choice of court clause or a

93. Presentation by Jean-Pierre Buyle (President of Avocats.be), 'Verslag van de eerste lezing namens de Commissie voor de Justitie'/'Rapport de la première lecture fait au nom de la commission de la Justice' (Report on the first reading on behalf of the Justice Committee), Parl. St./Doc. parl. (Parliamentary Documents): Kamer/Chambre (Belgian House of Representatives) 54, 3072/007, at 61.

94. Although the BIBC will be based in Brussels, it will not form part of the Brussels judicial district. This is an important point because, pursuant to Art. 157 bis of the Belgian Constitution, any changes to the language used in judicial matters in the Brussels judicial district are subject to the special majority requirements: Memorie van Toelichting/Exposé des motifs (Explanatory Memorandum), Parl. St./Doc. parl. (Parliamentary Documents): Kamer/Chambre (Belgian House of Representatives) 54, 3072/001, at 13.

95. Proposed Art. 576/1 of the Belgian Judicial Code. A very broad description of the nature of disputes is in line with the broad interpretation of the arbitration of disputes by an arbitral tribunal. G. Keutgen and G.-A. Dal, L'arbitrage en droit belge et international - Tome I - Le droit belge (3e édition revue et augmentée) (2015), at 115-16.

96. By contrast, the draft text establishing the Netherlands Commercial Court stipulates that the value of the dispute must exceed $€ 25,000$. (Draft) Amendment of the Code of Civil Procedure and the Act on Court Fees in Civil Proceedings to make it possible for cases to be handled in English by the international commercial chambers of the Amsterdam District Court and the Amsterdam Court of Appeal, which introduces a new Art. 30r(1) into the Dutch Code of Civil Procedure.

97. Proposed Art. 643/1(1) of the Belgian Judicial Code. 
reciprocal referral agreement after the emergence of a dispute. ${ }^{98}$ The parties may also agree to refer to the BIBC a dispute that is already pending before another court, subject, of course, to the other competence criteria being met. ${ }^{99}$

There is no nationality requirement whereby at least one of the parties has to have Belgian nationality. The BIBC complies with Belgian and European private international law on this point. ${ }^{100}$

The question is whether referral to a Belgian business court is, by itself, enough to bring a dispute before the BIBC. The Concept Netherlands Commercial Court Rules of Procedure, on which a public consultation is ongoing at the time of writing, require explicit referral to the Netherlands Commercial Court. ${ }^{101}$

\subsection{Businesses}

Ratione personae, there must always be a dispute between businesses. ${ }^{102}$ The Belgian concept of a business has recently been updated. ${ }^{103}$ The functional concept that used to apply has in certain cases been replaced by a purely formal concept.

In the context of the BIBC's competence, a business may be any of the following:

a. any individual performing a professional activity on a self-employed basis;

b. any legal person;

c. any other organisation that does not have legal personality.

Notwithstanding the foregoing, the following are not businesses $[\ldots]$ :

a. any organisation not having legal personality for which making payments is not part of its purpose and which in practice does not make payments to its members or to persons exercising a decisive influence on the organisation's policy;

b. any legal person under public law that does not offer goods or services on a market;

c. the Federal State, the regions, the communities, the provinces, the emergency services zones, the prelimi-

98. The proposed Art. 576/1(2) of the Belgian Judicial Code states that 'the parties' consent is demonstrated by an agreement or a provision of an agreement in which the parties resolve to submit to the BIBC all or certain disputes which have arisen or which may arise between them in respect of a defined legal relationship, whether contractual or not, or by the referral by another Belgian, foreign or international court or tribunal, including an arbitral tribunal, in which the parties' consent to the referral is declared.' This formulation is based on the simplest option provided for in Art. 7 of the UNCITRAL Model Law. Memorie van Toelichting/Exposé des motifs (Explanatory Memorandum), Parl. St./Doc. parl. (Parliamentary Documents): Kamer/Chambre (Belgian House of Representatives) 54, 3072/001, at 23.

99. Proposed Art. 566 of the Belgian Judicial Code. A referral from another court or tribunal requires the consent of all the parties to the dispute.

100. Proposed Art. 1385 quaterdecies/17 of the Belgian Judicial Code.

101. Concept Rules of Procedure for the International Commercial Chambers of the Amsterdam District Court (Netherlands Commercial Court) and the Amsterdam Court of Appeal (Netherlands Commercial Court of Appeal), available at: https://www.rechtspraak.nl/English/NCC (last visited on 18 July 2018).

102. Within the meaning of Art. I.1(1) of the Belgian Code of Economic Law (Wetboek van economisch recht/Code de droit économique).

103. Act of 15 April 2018 on company law reform, published in the Belgisch Staatsblad/Moniteur belge (Belgian Official Gazette) of 27 April 2018. nary emergency services zones ('prezones'), the Brussels Agglomeration, the municipalities/communes, the multi-municipality/commune zones, the intramunicipal territorial bodies, the French Community Commission, the Flemish Community Commission, the Joint Community Commission and the public social welfare centres.

The applied definition of a business implies that individuals performing a professional activity on a selfemployed basis - and therefore not in subordination can bring proceedings before the BIBC. ${ }^{104}$ The same applies to all legal persons under private law regardless of whether they offer goods or services on the market, for example non-profit organisations or foundations. ${ }^{105}$ Legal persons under public law that do not offer goods or services on a market are excluded from the concept of a business. De facto associations, in so far as they make no payments to their members, fall outside the applied concept of a business. ${ }^{106}$

A question then arises about foreign businesses that wish to bring a case before the BIBC but are not covered by the Belgian definition of a business. Under the Bill as it stands at the time of writing, they will not be entitled to bring disputes before the BIBC. ${ }^{107}$

\subsection{Extraneity}

Ratione materiae, the BIBC will be competent if an international element is involved. The interpretation of the notion of extraneity is based on the UNCITRAL Model Law. A dispute is referred to as international if it meets any of the following criteria: ${ }^{108}$

- the parties have their places of business in different States;

- a substantial part of the obligations of the commercial relationship or the place with which the subject-matter of the dispute is most closely connected is or are situated outside the State where the parties have their place of business;

104. The legislation does not clarify the term 'professional activity'. However, it does stipulate that an activity forming part of the normal management of an individual's personal property is not a professional activity. Long-term activities within the sharing economy are also covered by this definition of a business. J. Vananroye and R. Verheyden, 'Het toepassingsgebied van insolventieprocedures in Boek XX: focus op het nieuwe ondernemingsbegrip en de maatschap', in VGR Alumni (ed.) Recht in beweging - 25ste VRG Alumnidag (2018) 79, at 83.

105. S. De Dier and M. Wyckaert, 'De VZW herboren als onderneming', in VGR Alumni (ed.), Recht in beweging - 25ste VRG Alumnidag (2018) 53.

106. For further discussion of the formal concept of a business, see J. Stuyck, 'De begrafenis van de koopman: enkele inleidende beschouwingen over de nieuwe wet tot hervorming van het ondernemingsrecht', 2018/4 Revue de Droit Commercial Belge - Tijdschrift voor Belgisch Handelsrecht (RDC - TBH) 315 (2018), and E. Pieters, 'La loi du 15 avril 2018 portant réforme du droit de l'entreprise - présentation générale et regard critique', 59 Tax, Audit \& Accountancy 81 (2018).

107. Presentation by Prof. Geert Van Calster, KU Leuven, 'Verslag van de eerste lezing namens de Commissie voor de Justitie'/'Rapport de la première lecture fait au nom de la commission de la Justice' (Report on the first reading on behalf of the Justice Committee), Parl. St./Doc. parl. (Parliamentary Documents): Kamer/Chambre (Belgian House of Representatives) 54, 3072/007, at 64 .

108. Proposed Art. 576/1(3) of the Belgian Judicial Code. 
- the information required to resolve a dispute is located abroad.

The ratione materiae competence gave rise to a disagreement between the Belgian Council of State and the legislature. The former held that to comply with the Belgian Constitution, access to the BIBC must be restricted to disputes (i) which actually relate to international business and (ii) for which the use of English is necessary. ${ }^{109}$ This led to an additional criterion for the exercise of jurisdiction being integrated into the Bill, stating that 'the legal relationship between the parties shall provide sufficient objective evidence that a language other than Dutch, French or German has been customarily used'.

An unintended side effect of this extra criterion was pointed out during the hearing. ${ }^{110}$ For example, in instances where prior to an international trade dispute the foreign parties did not use English but only French, Dutch or German with their Belgian partners, this would rule out bringing a case before the BIBC.

As well as arguments concerning the existence of such sufficient objective evidence justifying the use of English, this would result in a difference in treatment. For example, an Italian company and a Chinese counterpart who use English or any language other than Dutch, French or German to communicate with each other would be perfectly entitled to bring a dispute before the BIBC. To avoid such a scenario, the legislature decided to scrap this additional criterion. ${ }^{111}$

\section{Rules of Procedure}

\subsection{UNCITRAL as a Reference Framework}

One of the most eye-catching innovations is the special set of procedural rules for the BIBC. ${ }^{112}$ The provisions of the Belgian Judicial Code do not in principle apply unless this is expressly provided. ${ }^{113}$ As a result, the Belgian Judicial Code will no longer provide a supplementary framework if the BIBC procedural framework

109. Opinion of the Belgian Council of State on this amendment, Parl. St./ Doc. parl. (Parliamentary Documents): Kamer/Chambre (Belgian House of Representatives)54, 3072/003, at 3-6.

110. Presentation by Prof. Geert Van Calster, KU Leuven, 'Verslag van de eerste lezing namens de Commissie voor de Justitie'/'Rapport de la première lecture fait au nom de la commission de la Justice' (Report on the first reading on behalf of the Justice Committee), Parl. St./Doc. parl. (Parliamentary Documents): Kamer/Chambre (Belgian House of Representatives) 54, 3072/007, at 63.

111. Amendment no. 8 by Sonja Becq and others, Parl. St./Doc.parl. (Parliamentary Documents): Kamer/Chambre (Belgian House of Representatives) 54, 3072/002, at 13 and also the Opinion of the Belgian Council of State on this amendment, Parl. St./Doc.parl. (Parliamentary Documents): Kamer/Chambre (Belgian House of Representatives) 54, 3072/003, at 3-6. This issue is also addressed in detail by the report on the first reading on behalf of the Justice Committee: Parl. St./Doc. parl. (Parliamentary Documents): Kamer/Chambre (Belgian House of Representatives) 54, 3072/007, at 39-41.

112. Included in Chapter XXVbis - Proceedings before the Brussels International Business Court (BIBC)

113. Art. 2 of the Bill establishing the Brussels International Business Court, Parl. St./Doc. parl. (Parliamentary Documents): Kamer/Chambre (Belgian House of Representatives) 54, 3072/001. makes no mention of it. The BIBC itself will resolve and plug procedural gaps when these emerge. ${ }^{114}$ The legislature assumes that this will only happen to a very limited extent. ${ }^{115}$

The rules of procedure for the BIBC are largely based on and taken from the UNCITRAL Model Law. ${ }^{116}$ UNCITRAL was chosen out of a desire to strike a balance between the continental and Anglo-Saxon legal systems, particularly with regard to evidence rules. ${ }^{117}$ Moreover, the international business community is already familiar with these procedural rules. There are currently 111 jurisdictions worldwide, including Belgium, ${ }^{118}$ with an arbitration law inspired by the UNCITRAL Model Law. ${ }^{119}$

\subsection{Exceptions}

To facilitate its application and to better fit the procedure into common Belgian procedural law, a number of adjustments and additions have been made to the UNCITRAL Model Law. ${ }^{120}$ Thus, the elimination of common procedural law applies only to the BIBC's organisation, competence and operation. ${ }^{121}$

The fact that the interaction between the BIBC and other state courts falls outside this specific procedural framework can be illustrated in tmo ways.

The first illustration relates to the issue of preliminary questions. Unlike an arbitral tribunal, the BIBC can ask preliminary questions. ${ }^{122}$ Rather than relaxing the lan-

114. Proposed Art. 1385quaterdecies/1 of the Belgian Judicial Code and Memorie van Toelichting/Exposé des motifs (Explanatory Memorandum), Parl. St./Doc. parl. (Parliamentary Documents): Kamer/Chambre (Belgian House of Representatives) 54, 3072/001, at 28. This also arises from the ban on the denial of justice. The legislature rejects criticism of the broad delegation, as it assumes that this will only occur to a limited extent in practice and always under the supervision of the Belgian Supreme Court.

115. Memorie van Toelichting/Exposé des motifs (Explanatory Memorandum), Parl. St./Doc. parl. (Parliamentary Documents): Kamer/Chambre (Belgian House of Representatives) 54, 3072/001, at 11.

116. UNCITRAL Model Law on International Commercial Arbitration (1985), with amendments as adopted in 2006, available at: www.uncitral.org/ uncitral/en/uncitral_texts/arbitration/1985Model_arbitration.html (last visited on 1 December 2018).

117. Memorie van Toelichting/Exposé des motifs (Explanatory Memorandum), Parl. St./Doc. parl. (Parliamentary Documents): Kamer/Chambre (Belgian House of Representatives) 54, 3072/001, at 11.

118. Act of 24 June 2013 amending the sixth part of the Judicial Code relating to arbitration, published in the Belgisch Staatsblad/Moniteur belge (Belgian Official Gazette) of 28 June 2013 and the (limited) amendments made by the Act of 25 December 2016 to amend the legal status of prisoners and the supervision of prisons, and containing various provisions related to the judicial authorities, published in the Belgisch Staatsblad/Moniteur belge (Belgian Official Gazette) of 30 December 2016.

119. https://uncitral.un.org/en/texts/arbitration/modellaw/ commercial_arbitration/status (last visited on 1 December 2018).

120. The Belgian Council of State had doubts about this. According to this principle, only the explicit provision of the Act establishing the BIBC will apply. This risked certain general rules of law not applying to the BIBC.

121. Memorie van Toelichting/Exposé des motifs (Explanatory Memorandum), Parl. St./Doc. parl. (Parliamentary Documents): Kamer/Chambre (Belgian House of Representatives) 54, 3072/001, at 13-14. Amendment no. 24 by Sonja Becq and others, Parl. St./Doc. parl. (Parliamentary Documents): Kamer/Chambre (Belgian House of Representatives) 54, 3072/009, at 2 here clarifies the legislation.

122. Presentation by Prof. Geert Van Calster, KU Leuven, 'Verslag van de eerste lezing namens de Commissie voor de Justitie'/'Rapport de la pre- 
guage requirements for other courts so that they can receive preliminary questions in English, the legislature has opted for a translation-based system. Thus, the BIBC will refer a preliminary question to the Belgian Supreme Court or the Belgian Constitutional Court in one of the official languages in which they are able to receive such questions. ${ }^{123}$

Preliminary questions to the Constitutional Court will be submitted in either Dutch or French, as chosen by the panel chairman. ${ }^{124,125}$ For preliminary questions to the Supreme Court, the same language arrangements will apply as for German. ${ }^{126}$

The BIBC may also refer a preliminary question to the European Court of Justice (CJEU) in Luxembourg. As a business court, the BIBC meets the CJEU's requirements. ${ }^{127}$ It can, of course, do this in English. ${ }^{128}$ Doubts concerning the permanent nature of the BIBC seem unfounded here. While the composition ends after it has handed down its judgment, the BIBC overall constitutes a permanent legal structure. ${ }^{129}$

The second illustration lies in the possibility for parties to appeal to the Supreme Court. ${ }^{130}$ They will be able to do

mière lecture fait au nom de la commission de la Justice' (Report on the first reading on behalf of the Justice Committee), Parl. St./Doc. parl. (Parliamentary Documents): Kamer/Chambre (Belgian House of Representatives) 54, 3072/007, at 64.

123. Namely Dutch, French or German. The BIBC will not be able to ask a question in English. In this regard, see the proposed Art. 2/1(3) of the Act of 15 June 1935 on the use of languages in judicial proceedings.

124. The procedure applying before the Belgian Constitutional Court is contained in Arts. 62 and 64 of the Special Act of 6 January 1989 on the Constitutional Court, published in the Belgisch Staatsblad/Moniteur belge (Belgian Official Gazette) of 7 January 1989. Therefore, the exclusion in Art. 73(4) of the Belgian Judicial Code does not apply. This choice was motivated by a pragmatic consideration, namely the wish to leave untouched a special act that can be amended only by special majority.

125. The legislature does not specify what factors the panel chairman must take into account when choosing the language. Art. 2/1, last paragraph of the Belgian Act of 15 June 1935 on the use of languages in judicial proceedings, published in the Belgisch Staatsblad/Moniteur belge (Belgian Official Gazette) of 22 June 1935. The cost of translating the judgment where the preliminary question is asked will be borne by the Belgian Treasury.

126. Proposed Art. 27bis of the Belgian Act of 15 June 1935 on the use of languages in judicial proceedings, published in the Belgisch Staatsblad/ Moniteur belge (Belgian Official Gazette) of 22 June 1935.

127. In case of doubt, the Court of Justice takes account of a number of factors, such as whether the body is established by law, whether it is permanent, whether its jurisdiction is compulsory, whether its procedure is inter partes, whether it applies rules of law and whether it is independent. Recommendations to national courts and tribunals, in relation to the initiation of preliminary ruling proceedings, OJ 2016 C 439/1, point 4; K. Lenaerts and P. Van Nuffel, Europees recht (2011), at 644, and the case law cited there.

128. In the case of questions referred for a preliminary ruling, the language of the case is that of the national court applying to the Court of Justice. Art. 37(3), Rules of Procedure of the Court of Justice of the European Union, 19 July 2016. In this case, it can be expected that the BIBC will ask preliminary questions in English

129. Case C-539/13 Judgment of the Court of 13 February 2014, Merck Canada Inc., C-555/13, EU:C:2014:92, point 24; Judgment of the Court of 12 June 2014, C-377/13, Ascendi, EU:C:2014:1754 and also the conclusion of the Opinion of Advocate General Szpunar delivered on 8 April 2014, Case C-377/13, Ascendi, EU:C:2014:246, in particular points $35-40$, providing a detailed analysis of the permanent nature as a prerequisite to be appointed as a 'court or tribunal of a Member State'.

130. Proposed Art. 609 of the Belgian Judicial Code. this in Dutch, French, German and English. ${ }^{131}$ If a party chooses Dutch or French, the entire proceedings will take place in that language. If a party opts for German or English, the Chairman will decide in which language (Dutch or French) the proceedings will be heard before the Supreme Court. ${ }^{132}$ The legislation does not specify what criteria the Chairman must take into account when choosing the language. As appeals to the Supreme Court in civil cases in Belgium must use a lawyer at the Supreme Court, the lawyer in question will be responsible for informing the plaintiff of any advantages and disadvantages of the language chosen. ${ }^{133}$ Consequently, the Supreme Court will not respond in English to an appeal brought before it against a BIBC judgment. In other respects, a Supreme Court appeal will follow the usual course. If a judgment is overturned, the case will be referred back to the BIBC but with a different composition. If the facts do not need to be assessed, the Supreme Court itself will hand down a final judgment in the case. ${ }^{134}$ As the Act on the use of languages in judicial proceedings has not been amended, the Supreme Court judgment will only be translated into French or Dutch, depending on the language of the proceedings. It would make sense that where the disputed ruling was handed down in English, the judgment should also be translated into that language, as happens with German. However, in the absence of an explicit legal basis, this seems unlikely. ${ }^{135}$

This issue needs to be addressed as the possibility of appealing to the Supreme Court is a major advantage of the BIBC: it makes up for the absence of other forms of appeal and represents a key difference from an arbitration ruling, where an appeal for annulment is possible only in limited cases. ${ }^{136,137}$

131. The right to appeal to the Supreme Court is provided for in Art. 147 of the Belgian Constitution. There are no exceptions. The proposed Art. 609 of the Belgian Judicial Code makes appeals to the Supreme Court, and the common law procedure from Arts. 1073 to 1121 of the Judicial Code, applicable to BIBC judgments.

132. The legislation refers to the 'premier président' ('First Chairman'), which in the case of the BIBC would mean the serving Chairman rather than the panel chairman.

133. Memorie van Toelichting/Exposé des motifs (Explanatory Memorandum), Parl. St./Doc. parl. (Parliamentary Documents): Kamer/Chambre (Belgian House of Representatives) 54, 3072/001, at 16.

134. As a result of a recent amendment to Arts. $1109 / 1$ and 1110 of the Belgian Judicial Code, this has become common law in Belgium. See Arts. 148 and 149 of the Act of 6 July 2017 on the simplification, harmonisation, computerisation and modernisation of provisions of civil law and civil procedural law as well as of the notarial profession, and containing various provisions related to the judicial authorities, published in the Belgisch Staatsblad/Moniteur belge (Belgian Official Gazette) of 24 July 2017.

135. For this purpose, Art. 28 of the Belgian Act of 15 June 1935 on the use of languages in judicial proceedings, published in the Belgisch Staatsblad/Moniteur belge (Belgian Official Gazette) of 22 June 1935, needs to be updated.

136. A comprehensive list of grounds for overturning judgments is given in Art. 1717 of the Belgian Judicial Code. G. Keutgen and G.-A. Dal, L'arbitrage en droit belge et international - Tome I - Le droit belge (3e édition revue et augmentée) (2015), at 529-30.

137. The possibility of appealing to the Supreme Court has been criticised on the grounds that (i) the Supreme Court will only be able to exercise limited oversight of the application of foreign legislation, (ii) the possibility of appealing to the Supreme Court may delay proceedings and 
Three reasons are cited for retaining the possibility of appealing to the Supreme Court. Firstly, this appears to be a constitutional requirement for state courts. ${ }^{138} \mathrm{Sec}-$ ondly, the particular procedural law governing the BIBC's organisation, competence and proceedings is a purely Belgian law, with the Supreme Court exercising oversight of the correct application of these legal provisions. Thirdly, in terms of the substantive law applied by the BIBC, the Supreme Court can check whether the choice of law is in accordance with Belgian PIL. If Belgian PIL provisions stipulate that Belgian law is applicable, the conventional test will be used, whereas if foreign law applies, the Supreme Court will use a less stringent test. ${ }^{139,140}$

\section{Funding}

\subsection{General Remarks}

The requirement that the $\mathrm{BIBC}$ be budget neutral is crucial. ${ }^{141}$ As regards the criticism that the establishment of the BIBC will be at the expense of the conventional courts, which are already under budgetary pressure, two points need to be made. ${ }^{142}$

(iii) translation issues may arise because the BIBC's working language, English, is not a working language of the Supreme Court. An amendment has been tabled to rule out the possibility of appealing to the Supreme Court in the case of BIBC judgments: Parl. St./Doc. parl. (Parliamentary Documents): Kamer/Chambre (Belgian House of Representatives) 54, 3072/012. A further Council of State opinion has been sought in this regard. At the time of writing, this (third) opinion is not yet available.

138. Art. 147 of the Belgian Constitution; 'Verslag van de eerste lezing namens de Commissie voor de Justitie'/'Rapport de la première lecture fait au nom de la commission de la Justice' (Report on the first reading on behalf of the Justice Committee), Parl. St./Doc. parl. (Parliamentary Documents): Kamer/Chambre (Belgian House of Representatives) 54, 3072/007, at 19

139. La Générale des Carrières et des Mines v. R.L. \& Umicore, Hof van Cassatie/Cour de Cassation (Belgian Supreme Court), 18 March 2013, C.12.0031.F; J. Verhellen, 'Buitenlands recht in Belgische rechtbanken: roeien met korte riemen', 2018/1 Revue de Droit Commercial Belge - Tijdschrift voor Belgisch Handelsrecht (RDC - TBH) 23 (2018); P. Wautelet, 'Foreign Law in Belgian Courts - From Theory to Practice', in Y. Nishitani (ed.), Treatment of Foreign Law - Dynamics towards Convergence?, (2017) at 85, available at: https://papers.ssrn.com/sol3/ papers.cfm?abstract_id=2521332 (last visited on 1 December 2018)

140. 'Verslag van de eerste lezing namens de Commissie voor de Justitie'/ 'Rapport de la première lecture fait au nom de la commission de la Justice' (Report on the first reading on behalf of the Justice Committee), Parl. St./Doc. parl. (Parliamentary Documents): Kamer/Chambre (Belgian House of Representatives) 54, 3072/007, at 19.

141. Policy Statement of the Minister of Justice - 8 November 2017, Parl. St./Doc. parl. (Parliamentary Documents): Kamer/Chambre (Belgian House of Representatives) 54, 2708/029, at 49. This budget-neutrality has been questioned as the public authorities still have to pay certain costs, for example for accommodation and some salaries and translation costs.

142. Data from the Council of Europe's European Commission for the Efficiency of Justice (CEPEJ) shows that only 4 per cent of the costs of Belgium's judicial system are covered by court fees, well below the European average of 18 per cent (CEPEJ, European Judicial Systems: Efficiency and Quality of Justice (2016), at 11). The 2018 edition of the CEPEJ report on the efficiency and quality of European judicial systems confirms this trend as according to 2016 data, $5 \%$ of the costs of Belgium's judicial system are covered by court fees. CEPEJ, European Judicial Systems: Efficiency and Quality of Justice (2018), at 69.
Firstly, the Chairman and the panel chairman will come from other courts and tribunals. While these professional judges are sitting at the BIBC (in the case of the panel chairman) or overseeing administrative matters (in the case of the Chairman), they will not be sitting at these other courts. Courts that temporarily have to do without one of their judges will therefore be paid financial compensation. ${ }^{143}$ Financial compensation will also be paid for the registry of the Brussels Court of Appeal. ${ }^{144}$

It could further be argued that an international trade dispute could just as easily be brought before a conventional business court. However, given the complexity and international nature of such disputes, trying to have the matter settled by a court that is less conversant with international business law would also require a substantial commitment of both time and resources, and the parties would not be paying a higher registration fee to cover the costs.

The BIBC's impact on the work of other courts and tribunals will be limited as (i) the conventional courts will be partially or fully relieved of the burden of the timeconsuming and complex work of resolving international trade disputes, and (ii) the parties, by paying a higher registration fee, will in principle cover all the costs themselves. ${ }^{145}$

As the number of cases is difficult to gauge in advance, estimating how much revenue will be generated is not easy. The legislature is working on the assumption that a maximum of twenty-five cases will be initiated per year in the initial period. ${ }^{146}$ However, it is unfortunate that there has been no quantified economic and financial impact assessment along the lines of the one conducted ahead of the establishment of the Netherlands Commercial Court. ${ }^{147}$

\subsection{Costs}

In principle, the costs of the BIBC's intervention will be borne by the unsuccessful parties. Unnecessary costs will be paid by the party that erroneously incurred

143. This amounts to $€ 4,747$ per case for the court supplying the panel chairman.

144. Memorie van Toelichting/Exposé des motifs (Explanatory Memorandum), Parl. St./Doc. parl. (Parliamentary Documents): Kamer/Chambre (Belgian House of Representatives) 54, 3072/001, at 34. In this respect, the Bill responds to the criticism of the High Council of Justice, 'Avis d'office : Avant-projet de loi instaurant la Brussels International Business Court', at 6-7.

145. E. Dirix, 'Gezocht: een statisticus voor het grondwettelijk Hof', 81/14 Rechtskundig Weekblad 522 (2017), which asserts the following: 'In many European countries, there is a noticeable trend away from endlessly funding the costs of accessing justice from the general budget, towards passing on these costs to those who use the judicial system. In some countries, efforts are even being made to ensure that court fees cover all the costs. This is far from the case in Belgium. In general, it is noted that the data from the Council of Europe (CEPEJ) indicate that in our country [Belgium] only $4 \%$ of the costs of the judicial system are covered by court fees, whereas the European average is $18 \%$.'

146. Memorie van Toelichting/Exposé des motifs (Explanatory Memorandum), Parl. St./Doc. parl. (Parliamentary Documents): Kamer/Chambre (Belgian House of Representatives) 54, 3072/001, at 33.

147. The Dutch legislature is working on the basis of a launch phase with start-up costs of $€ 3.8$ million for the Netherlands Commercial Court: Raad voor de rechtspraak (Council for the Judiciary), 'Plan tot oprichting van de Netherlands Commercial Court' (2015), at 14. 
them. ${ }^{148}$ Parties are expected to reach agreement on this issue, either before or after a dispute arises.

As well as the standard 'roll fees' for entering the case on the court roll, the parties will be required to pay a higher registration fee, ${ }^{149}$ of around $€ 20,000$, as a 'retributie'/ 'rétribution'. ${ }^{150}$ In Belgium, this term refers to a charge for a specific service performed by the public authorities for the benefit of the person liable for payment. The sum charged must always be in reasonable proportion to the service provided. ${ }^{151}$ The level of the registration fee is therefore directly related to the selffinancing nature of the BIBC. Accordingly, the preparatory works explain in detail how the amount of $€ 20,000$ came about. ${ }^{152}$ The exact amount that parties pay will vary on a case-by-case basis as some costs, for example the judges' travel expenses, are not known in advance. ${ }^{153}$ Concerns have been raised, justifiably, about whether the amount of the registration fee will be a barrier to the use of the BIBC by smaller businesses. At any rate, compared with arbitration, the registration fee does not seem prohibitively high. ${ }^{154}$ It is also similar to the sums charged elsewhere for similar courts. In the Netherlands, the registration fee for the Netherlands Commercial Court is budgeted at $€ 15,000$ at first instance and $€ 20,000$ for appeals. However, the BIBC will rule at first and last instance.

It should not be forgotten that submitting a complex dispute to a conventional business court is a costly matter. If various relevant documents also have to be translated into Dutch or French, it may be more efficient and

148. Proposed Art. 1385 quaterdecies/21 of the Belgian Judicial Code. This Art. is taken from Arts. 1017-1021 of the Belgian Judicial Code with the additional specification that the expenses statements must be approved by the Chairman of the BIBC before they can be considered. Memorie van Toelichting/Exposé des motifs (Explanatory Memorandum), Parl. St./Doc. parl. (Parliamentary Documents): Kamer/Chambre (Belgian House of Representatives) 54, 3072/001, at 38.

149. This is the registration fee as referred to in the proposed Art. 1385quaterdecies/11 of the Belgian Judicial Code. The registration fee will cover (i) the various court and registration fees, (ii) the price and remuneration and wages for the judicial documents, (iii) the price of issuing the judgment, (iv) the expenses involved in any investigative measures, (v) the expenses statements of the judges and registrars, approved by the serving Chairman of the BIBC, and the costs of documents when these have been drawn up solely for the purposes of the proceedings. In case of referral to the BIBC by a Belgian court, only the registration fee will be payable.

150. Memorie van Toelichting/Exposé des motifs (Explanatory Memorandum), Parl. St./Doc. parl. (Parliamentary Documents): Kamer/Chambre (Belgian House of Representatives) 54, 3072/001, at 34. Pursuant to the proposed Art. 1385quaterdecies/11 of the Belgian Judicial Code, the exact amount will be laid down in a subsequent implementing decree.

151. If they are not in reasonable proportion, it is a tax rather than a 'retributie'/'rétribution'. Thus, roll fees, as they only make a very modest contribution to the actual costs of proceedings, are regarded as taxes.

152. Memorie van Toelichting/Exposé des motifs (Explanatory Memorandum), Parl. St./Doc. parl. (Parliamentary Documents): Kamer/Chambre (Belgian House of Representatives) 54, 3072/001, at 34.

153. Memorie van Toelichting/Exposé des motifs (Explanatory Memorandum), Parl. St./Doc. parl. (Parliamentary Documents): Kamer/Chambre (Belgian House of Representatives) 54, 3072/001, at 129.

154. The high cost of arbitration remains one of the main hurdles for parties. Queen Mary University of London (2018), 2018 International Arbitration Survey - The Evolution of International Arbitration, at 8. economical to bring the dispute before the BIBC. This is a decision for the individual business to make.

\subsection{Remuneration}

As the court's chief of staff, the Chairman can expect to receive an annual salary supplement of $€ 3,000$. The panel chairman will receive a salary supplement of $€ 450$ per case. ${ }^{155}$ The lay judges will, given the BIBC's prestige and the reputational benefits of working for this court, receive a lump-sum remuneration of $€ 5,500$ per case. It is important that it is a lump sum as lay judges will not submit invoices for services rendered. Remarkably, this amount was based on judges being available for one working week per case, ${ }^{156}$ which seems highly optimistic.

\section{Conclusion}

Clearly, by establishing the BIBC, Belgium is seeking to acquire a share of the global market for resolving international trade disputes. As the capital of Belgium and the de facto capital of Europe, Brussels is the epitome of an international city. It is also home to many European and international institutions and company headquarters, making it a hub for international business. Belgium's open, export-driven economy means that companies often do business across national borders and disputes quickly acquire an international dimension.

Although the BIBC is still work in progress, an effective English-speaking business court has the potential to deliver substantial benefits for business while also consolidating Brussels' status as an international litigation hub.

The BIBC's legal architecture will give it some major advantages, enabling international expertise to be mobilised and brought together in one court. The challenge for the BIBC now is to win over the business community. English-language case handling must go hand in hand with efficient procedures and high-quality judgments, meaning that modern premises and high-tech facilities are a must.

Finally, the establishment of the BIBC must be accompanied by a professional PR campaign targeting interested parties in Belgium and beyond, so that the business community is aware of the new court and can incorporate it into dispute resolution strategies. ${ }^{157}$

155. Memorie van Toelichting/Exposé des motifs (Explanatory Memorandum), Parl. St./Doc. parl. (Parliamentary Documents): Kamer/Chambre (Belgian House of Representatives) 54, 3072/001, at 21.

156. Memorie van Toelichting/Exposé des motifs (Explanatory Memorandum), Parl. St./Doc. parl. (Parliamentary Documents): Kamer/Chambre (Belgian House of Representatives) 54, 3072/001, at 32-3.

157. Text concluded on 1 January 2019 